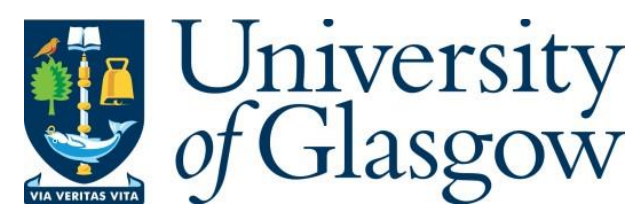

Naylor, S. (2017) Historical geography in Transactions. Transactions of the

Institute of British Geographers, 42(4), pp. 485-488. (doi:10.1111/tran.12222)

There may be differences between this version and the published version. You are advised to consult the publisher's version if you wish to cite from it.

http://eprints.gla.ac.uk/155097/

Deposited on: 12 January 2018

Enlighten - Research publications by members of the University of Glasgow http://eprints.gla.ac.uk 


\title{
Editorial: Historical Geography in Transactions
}

\begin{abstract}
This editorial reviews recent works of historical geography published in Transactions. It highlights a number of prominent themes that bind the papers together: the historical geographies of geopolitics, the state and territory; landscape and environmental change; matters of memory and commemoration; and the production, practice and provision of knowledge.
\end{abstract}

Key words Historical geography; geopolitics; territory; environmental change; memory; knowledge production

The explicit aim of Transactions is to publish articles that make a major theoretical, conceptual or empirical contribution to the development of geographical research from right across the social and physical sciences and humanities. That said we want to use a series of forthcoming editorials to highlight the depth and diversity of highquality scholarship published in the journal in particular fields of geographical inquiry. I will make a start here with a spotlight on recent work in Transactions on historical geography. The papers I have chosen come from a diverse set of authors some of whom might not even consider themselves as historical geographers at all working in a wide range of institutional settings and based in a number of countries, including the UK, Ireland, the Netherlands, the United States, Canada, and Australia. There are some recurring themes and concerns that connect these papers in fascinating ways and which I use to organise my discussion below. We can treat these themes as indicative of some of the leading research agendas in historical geography today - the historical geographies of geopolitics, the state and territory; landscape and environmental change; matters of memory and commemoration; and the production, practice and provision of knowledge.

Richardson's paper, 'Beyond the nation and into the state', is a good place to begin a review of recent work on the historical geographies of geopolitics, the state and territory. It focuses on a series of contested islands on one of Russia's most isolated borders, which were 'neither fully within, nor without the state' $(2016,201)$. Richardson argues that during the 1990s 'the quotidian realities and challenges of life 'beyond' the state for the Southern Kuril islands had profound implications for how discourses around state, nation, sovereignty and identity' were conceived. Clark and Jones are also interested in the historical role of the state in making territories. Taking Iceland as a case-study they examine "how pre-modern territorialisation shaped state territorialities, and how state periodisation arises from political order imbricated with the materialities of territory' $(2017,123)$. Klinke's paper examines Fallex 66, the first of a series of NATO wargames that simulated a nuclear war and its aftermath on German territory. It also considers how the war games were interpreted in East Germany, which read the war game as a 'forbidden and obscene enjoyment of selfannihilation' (2016, 109). Leshem and Pinkerton consider the long history of the idea of no-man's land as a space between territories that has been produced by forces of abandonment and enclosure. The authors analysis of the term's use over time includes the obvious reference point of the First World War but then extends it to Roderick Murchison's discussion of the supposedly barbarous and ungovernable areas surrounding the Nile south of Khartoum, the enclosure of burial grounds in advance 
of the Black Death in the 14th century, and the exclusion zone drawn around the Chernobyl nuclear power plant in the mid-1980s. Hodder (2017) investigates how ideas of peace have been circulated, adapted and even resisted. He looks in particular at the World Peace Brigade's collaboration with the Northern Rhodesian independence movement in 1962, where the Brigade developed an internationalist concept that emphasised world community, while on the other hand a local concept of peace was developed that adapted pacifism for nationalist movements. Also focusing on African decolonisation, Craggs and Neate (2017) discuss the global mobility of urban policy between Africa and Britain. They consider the material and ideological connections between late colonial development in Nigeria, British reconstruction and international consultancy. In doing so they deploy the notion of careering, that is the way in which individual professional lives connected spaces of late colonial development.

The intersection of geopolitics and environmental mapping is proving to be fertile ground for historical geographers. Akhter (2017) considers the hydropolitics of water distribution in the Indus Basin and the depoliticisation of water measurement by a hydraulic bureaucracy, using the example of the Indus Water Treaty of 1960 and the Indus-related border conflict between Pakistan and India in the decade after independence in 1947. Tyner and Will's (2015) paper details the structures of violence that contributed to deaths through famine-related causes in 'post-conflict' Cambodia. The focus of these authors is on the violence inflicted by environmental management policies of the Communist Party of Kampuchea in the second half of the 1970s. Taking a very different set of themes and period, Clarke and Rendall (2015) investigate changing coastal dune management practices in Western Europe over the last 700 years, leading them to argue that historical evidence should be used to inform contemporary debates on future management of coastal dunes. Although the empirical material they use is very recent, McEwen et al (2017) also argue that environmental histories - in this case, flood histories and memories - should be incorporated into strategies for future flood resilience. Meanwhile Comber et al consider the mapping of coastal land use change from 1965 to 2014, where they review the origins and impacts of differences in the way that land use classes have been measured and reported, concluding that 'these differences have important implications for analyses of historic thematic data' $(2016,457)$. Matless's paper on the 'Anthroposcenic' considers the geological term Anthropocene through the ideas of landscape and time, suggesting that landscape 'becomes emblematic of environmental transformation' $(2017,363)$. Like many of the other papers mentioned here, the paper concentrates on processes of environmental change at the coast, and points to the complex interconnections between past, present and future: 'The coastal Anthroposcenic carries complex capacity to project across time, with nuances of memory and history challenging any formulations of the Anthropocene seeking more straightforward past dating and future projection' $(2017,373)$.

Memory has been a topic of a number of other recent papers in Transactions. For instance, DeLyser engages with recent creative approaches to the archive in geography to explore 'archival autoethnography', that is the author's own collection and contribution to the archive along with a critical engagement with those same practices. Sumartojo looks at Australia's Anzac Day to consider shared annual commemorative ceremonies and their role in connecting residents to particular versions of the nation, to the past and to one another. Sumartojo deploys the term 
'commemorative atmospheres' 'to explore how such events 'feel', arguing that spatially-specific affective experience can work to connect individuals to the nation' $(2016,541)$. Benwell's paper investigates the effects that 'memories and their attendant landscape manifestations and rituals' had on children growing up on the Falklands Islands after the 1982 conflict, tracing the circulation of certain memories between generations and informing young people's geopolitical subjectivities (2016, 121). Finally, Muzaini (2015) uses the experiences of people who went through the Second World War in Malaysia to consider processes of forgetting as well as the reemergence of memory.

There has been an up-swell of interest in the historical geographies of knowledge production and its attendant practices, with a lot of attention given to various forms of scientific activity and ideas. Patchett's paper studies the working spaces and working practices of taxidermists and their relations to 19th-century natural history inquiry. Her attempts to study bodies at work in the past necessitated 'creatively curating and narrating historical geographies of craftwork' $(2017,391)$. Patchett's attention to working bodies links well to Rioux's (2015) study of uneven bodies as sites of social and economic processes, while her 'deliberate curation of historical remainders' (2017, 392) connects productively with some of DeLyser's concerns above. Like Patchett, Finnegan focuses on a practice that is difficult for us to capture today. In 'Finding a scientific voice' he discusses the science lectures of Michael Faraday and Thomas Henry Huxley. In his reconstruction of the platform performances of these Victorian men of science, Finnegan argues that geography, in the form of specific material and cultural locations, was crucial for making science sound and look right. Two other recent studies of the historical geographies of knowledge focus on more conventional source material: books and illustrations. In his paper on German Enlightenment print culture Bond argues for greater attention to 'periodical geography', that is to 'the geographies of knowledge, reading, commerce and colonialism that shaped how periodicals were produced, circulated and read' (2017, 59). Meanwhile, Johnson considers the botanical illustrations of Charlotte WheelerCuffe, who travelled, observed and hunted plants in Burma in the late nineteenth and early twentieth centuries. Johnson shows that Wheeler-Cuffe's long residency in Burma allowed her to 'develop some personal local prestige as an expert on the colony's plant geographies' (2017, 429). Finally, Jöns, Mavroudi and Heffernan (2015) consider the 'elective diaspora' of university academics in the post-war period. Jöns et al focus on a transnational mobility scheme that brought American academics to the Federal Republic of Germany in the 1950s and use the example to argue that diasporic networks need to be theorised as often civic in nature.

There is also an increasing amount of exciting work being done on the historical geographies of education and pedagogy. Sharing many connections with Hodder's paper, discussed above, Ferretti considers historical geographies of peace in terms of the 'didactic methods for peace education' $(2016,570)$. Focusing on the work of French geographers Marie-Thérèse Maurette and Paul Dupuy at the Geneva International School in the early twentieth century, Ferretti traces the importance of cosmopolitanism, multilingualism and extra-academic voluntarism in their 'pedagogical activism' $(2016,580)$. Mills' paper on the Jewish Lads' Brigade and Club in post-war Manchester also pays attention to voluntarism and the 'spatialities of informal education', where she conceptualises youth work as 'a series of localised and inherently spatial practices' $(2015,523)$. Mitchell looks at 'how humanitarian 
initiatives in black education were mobilised in relation to differing moments of international and domestic colonialism, nation-building, national security and global aspirations at the heart of American empire'. Mitchell examines three historical moments during which 'humanitarian reasoning and webs of belief about the proper intellectual development of African Americans' were conceived (2017, 349). Across these three periods Mitchell detects a relationship between humanitarian educational reason and 'interlinked anxieties of freedom, security and economic development of the nation' (2017, 358). Finally, Moore's (2016) paper connects well with Mitchell's work in that it too explores the historical geographies of philanthropy. Moore examines the philanthropic and social work carried out by middle-class women outside the home in early-twentieth century Lancashire. By engaging in child rescue, temperance work, infant welfare and maternal education services, Moore argues that these women were able to carve out their claims to citizenship despite not being granted any formal rights or entitlements by the state.

The purpose of this editorial has been to highlight the breadth, diversity and high quality of historical geography scholarship in recent volumes of Transactions. Much of what we have found here is unsurprising and reflects broader trends in the sub-

discipline. Research into the histories of environments and landscapes has been a mainstay of historical geography for a long time now, whilst work on the historical geographies of science has gained increased traction in the field over the last 25 years or so. It is exciting to see work that is developing newer areas of historicalgeographical interest, such as into educational practices, geopolitics, histories of the future and creative archival methods. Finally, it is only fair to note that some of the authors of the papers I have discussed would not recognise my description of their work as historical geography. However, the fact that so much scholarship across human geography is mobilising historical methods and marshalling historical data to support its arguments is the best evidence I could present to show that historicalgeographical scholarship is in rude health.

\section{References}

Akhter M 2017 Desiring the data state in the Indus Basin Transactions of the Institute of British Geographers 42 377-389

Benwell M C 2016 Encountering geopolitical pasts in the present: young people's everyday engagements with memory in the Falkland Islands Transactions of the Institute of British Geographers 41 121-33

Bond W D 2017 Plagiarists, enthusiasts and periodical geography: A.F. Büsching and the making of geographical print culture in the German Enlightenment, c.1750-1800 Transactions of the Institute of British Geographers 42 58-71

Clark J and Jones A 2017 (Dis-)ordering the state: territory in Icelandic statecraft Transactions of the Institute of British Geographers 42 123-38

Clarke M L and Rendall H M 2015 'This restless enemy of all fertility': exploring paradigms of coastal dune management in Western Europe over the last 700 years Transactions of the Institute of British Geographers 40 414-29 
Comber A J, Davies H, Pinder D, Whittow J B, Woodhall A and Johnson S C M 2016 Mapping coastal land use changes 1965-2014: methods for handling historical thematic data Transactions of the Institute of British Geographers 41 442-59

Craggs R and Neate $\mathbf{H} 2017$ Post-colonial careering and urban policy mobility: between Britain and Nigeria, 1945-1990 Transactions of the Institute of British Geographers 42 44-57

DeLyser D 2015 Collecting, kitsch and the intimate geographies of social memory: a story of archival autoethnography Transactions of the Institute of British Geographers 40 209-22

Ferretti F 2016 Geographies of peace and the teaching of internationalism: MarieThérèse Maurette and Paul Dupuy in the Geneva International School (1924-1948) Transactions of the Institute of British Geographers 41 570-84

Finnegan D 2017 Finding a scientific voice: performing science, space and speech in the 19th century Transactions of the Institute of British Geographers 42 192-205

Hodder J 2017 Waging peace: militarising pacifism in Central Africa and the problem of geography, 1962 Transactions of the Institute of British Geographers 42 $29-43$

Johnson N C 2017 On the colonial frontier: gender, exploration and plant-hunting on Mount Victoria in early 20th-century Burma Transactions of the Institute of British Geographers 42 417-431

Jons H, Mavroudi M and Heffernan M (2015) Mobilising the elective diaspora: US-German academic exchanges since 1945 Transactions of the Institute of British Geographers 40 113-127

Klinke I 2016 Self-annihilation, nuclear play and West Germany's compulsion to repeat Transactions of the Institute of British Geographers 41 109-20

Leshem N and Pinkerton A 2016 Re-inhabiting no-man's land: genealogies, political life and critical agendas Transactions of the Institute of British Geographers $4141-53$

McEwen L Garde-Hansen J, Holmes A, Jones O and Krause F 2017 Sustainable flood memories, lay knowledges and the development of community resilience to future flood risk Transactions of the Institute of British Geographers 42 14-28

Matless D 2017 The Anthroposcenic Transactions of the Institute of British Geographers 42 363-376

Mills S 2015 Geographies of youth work, volunteering and employment: the Jewish Lads' Brigade and Club in post-war Manchester Transactions of the Institute of British Geographers 40 523-35 
Mitchell K 2017 Education, race and empire: a genealogy of humanitarian governance in the Unite States Transactions of the Institute of British Geographers 42 349-362

Moore F 2016 'A band of public-spirited women': middle-class female philanthropy and citizenship in Bolton, Lancashire before 1918 Transactions of the Institute of British Geographers 41 149-62

Muzaini H 2015 On the matter of forgetting and 'memory returns' Transactions of the Institute of British Geographers 40 102-12

Patchett M 2016 Taxidermy workshops: differently figuring the working of bodies and bodies at work in the past Transactions of the Institute of British Geographers 42 390-4-4

Richardson P B 2016 Beyond the nation and into the state: identity, belonging, and the 'hyper-border' Transactions of the Institute of British Geographers 41 201-15

Rioux S 2015 Capitalism and the production of uneven bodies: women, motherhood and food distribution in Britain c.1850-1914 Transactions of the Institute of British Geographers 40 1-13

Sumartojo S 2016 Commemorative atmospheres: memorial sites, collective events and the experience of national identity Transactions of the Institute of British Geographers 41 541-53

Tyner J A and Will R 2015 Nature and post-conflict violence: water management under the Communist Party of Kampuchea, 1975-1979 Transactions of the Institute of British Geographers 40 362-74 